\title{
Development of Electronic Commerce on Tourist Traveling
}

\author{
W Novianti ${ }^{*}$, R D Pratama ${ }^{2}$ \\ ${ }^{1}$ Departemen Manajemen, Universitas Komputer Indonesia, Indonesia \\ 2Departemen Sistem Informasi, Universitas Komputer Indonesia, Indonesia \\ Email: *windi.novianti@email.unikom.ac.id
}

\begin{abstract}
The research aims to specify the effect of the expansion of e-commerce on the ticket booking business. The method used in this research was descriptive analysis, which was a method that presents a complete picture of the phenomena that occur in the case raised. Besides that, this study identifies the extent of the impact resulting from the development of e-commerce on the ticket booking business, as well as the benefits to be gained from the results of the ticket booking. The results of this study prove that booking tickets online is very efficient and makes it easy in the transaction process. Based on the analysis conducted, the impact of the development of e-commerce on the online ticket booking business has a major effect on the development of e-commerce. The research concluded that the effect of e-commerce development has a big influence on people's interest in booking tickets online.
\end{abstract}

\section{Introduction}

At this time Information Technology has changed the face of the world from the real world to the virtual world [1]. Therefore, information technology can be utilized in various fields of work. Technology in the world has evolved in recent years which has led to improvements in various fields making life easier, less complicated, and extra comfortable [2]. The development of information technology is very helpful in running its business, information technology provides information accurately, quickly and precisely to provide convenience in transactions. Sophisticated information technology causes entrepreneurs to take advantage of information technology that is increasing so that competition between entrepreneurs becomes tighter. One form of information technology that is currently developing is the spread, purchase, sale, marketing of goods and services through electronic network systems such as electronics commercial [3].

E-commerce has played the biggest part in the farthest reach of business economics [4]. Then, e-commerce is used as an opportunity in doing business by entrepreneurs. E-commerce, in the popular sense, is a business transaction such as selling electronic networks or the internet [4]. Products produced from online businesses one of which is engaged in tourism services. Ecommerce brings new business opportunities to the global travel and tourism industry [5]. Local travel agents implement a global distribution system by adjusting strategy, marketing, 


\section{International Journal of Research and Applied Technology}

$1(2)(2021) 263-270$

Journal homepage: https://ojs.unikom.ac.id/index.php/injuratech

and expanding services to realize an increased competitive advantage [5]. Local Travel Agents have improved services globally by registering with online travel agents, and interorganization reservation systems [5]. Besides, many businesses have developed websites that offer online planning, ordering, and payment for added convenience to consumers [5]. Travel tickets on the booking website are available on the smartphone application, thus, the website can be accessed anywhere using a mobile phone [6]. Electronic ticket technology can be classified according to the way they are used to payment [7]. Globally, information technology is widely used in industries such as aviation and travel, hospital, tour operators, travel agents, reservation systems for tourism and destinations [8]. The purpose of these facilities in online ticket booking is to facilitate consumers to order tickets according to their needs.

The research aims to determine the impact of the development of e-commerce on the ticket booking business. The method used in this research was descriptive analysis, which method presents a complete picture of the phenomena that occur in the case being raised. Besides that, this study identifies the extent of the impact resulting from the development of e-commerce on the ticket booking business, as well as the benefits to be gained from the results of the ticket booking.

\section{Method}

The research method used was descriptive analysis method. This method is an evolutionary process discussing the phenomenon that is being investigated and must to seen a relationship with the question or question being explored [9]. Qualitative research approaches are widely used for descriptive studies: phenomenon and qualitative descriptive descriptions [10]. The function of the descriptive analysis method was to present a complete picture of the phenomena that occurred in the case being raised. This study identified the extent of the impact resulting from the development of e-commerce on the ticket booking business, as well as the benefits derived from the results of booking tickets.

\section{Results and Discussion}

Figure 1 shows that Information technology is increasingly supporting the development of business. One of them is in the business of booking travel tickets. So many services in booking tickets online because booking tickets online are very efficient and easy in the transaction process. Besides, complete facilities and promos in the form of price discounts that many people are increasingly interested in using them. 
International Journal of Research and Applied Technology

1(2)(2021) 263-270

Journal homepage: https://ojs.unikom.ac.id/index.php/injuratech

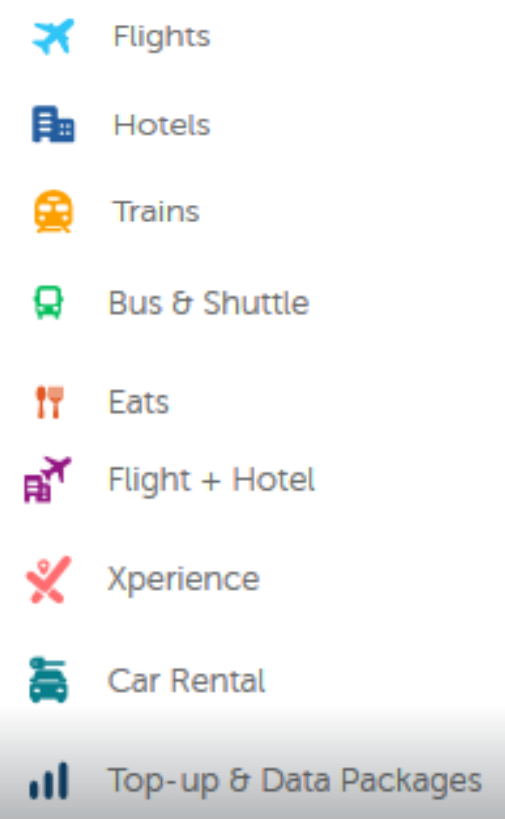

Figure 1. Facilities on online ticket booking.

Figure 2 shows the facilities available for booking tickets online are very diverse such as transportation, accommodation, destinations to be addressed restaurants or tourist destinations, data package top-up and e-money top-up, as well as other travel support features.
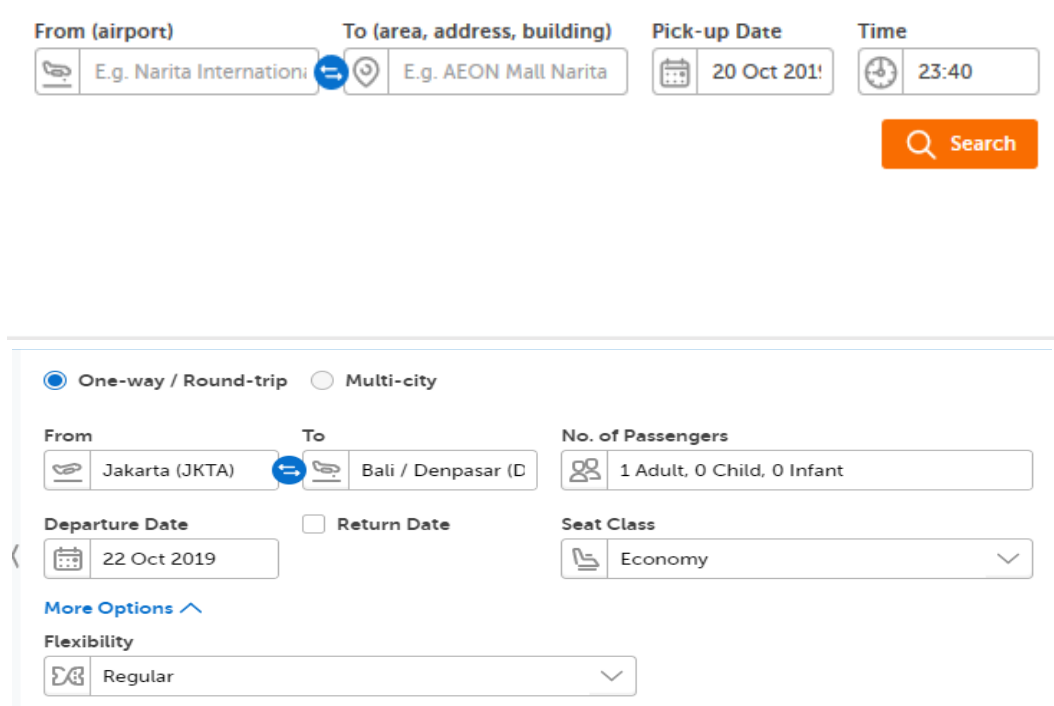

Figure 2. Airplane ticket booking process. 
Figure 3 shows one of the facilities available for online ticket booking is the airplane ticket booking. The choices available on airplane ticket reservations consist of the city of origin, the city to be addressed, the type of class to be used, the date and time of departure.

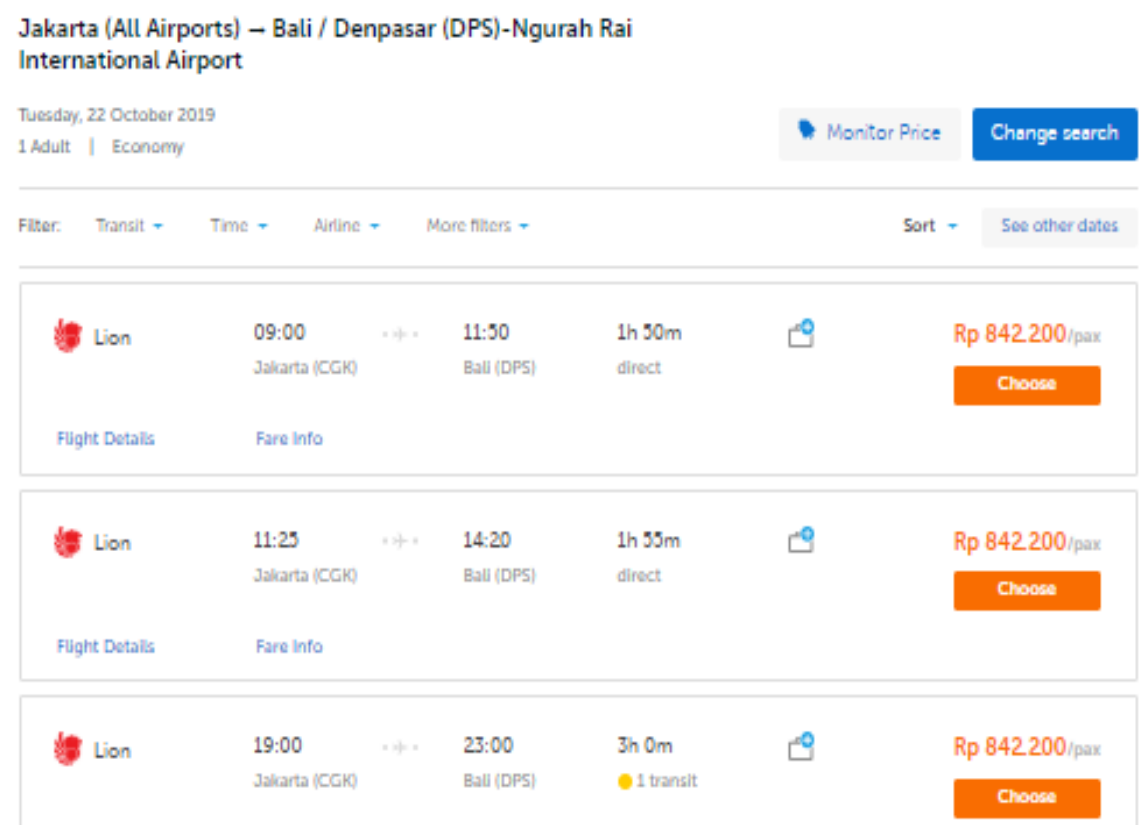

Figure 3. List of suggested flight ticket prices based on price order, and time of departure.

Figure 4 shows the availability of recommendations for flight ticket prices that have been sorted by lowest to most expensive, the type of airline used, and the time of departure. 
International Journal of Research and Applied Technology

$1(2)(2021) 263-270$

Journal homepage: https://ojs.unikom.ac.id/index.php/injuratech

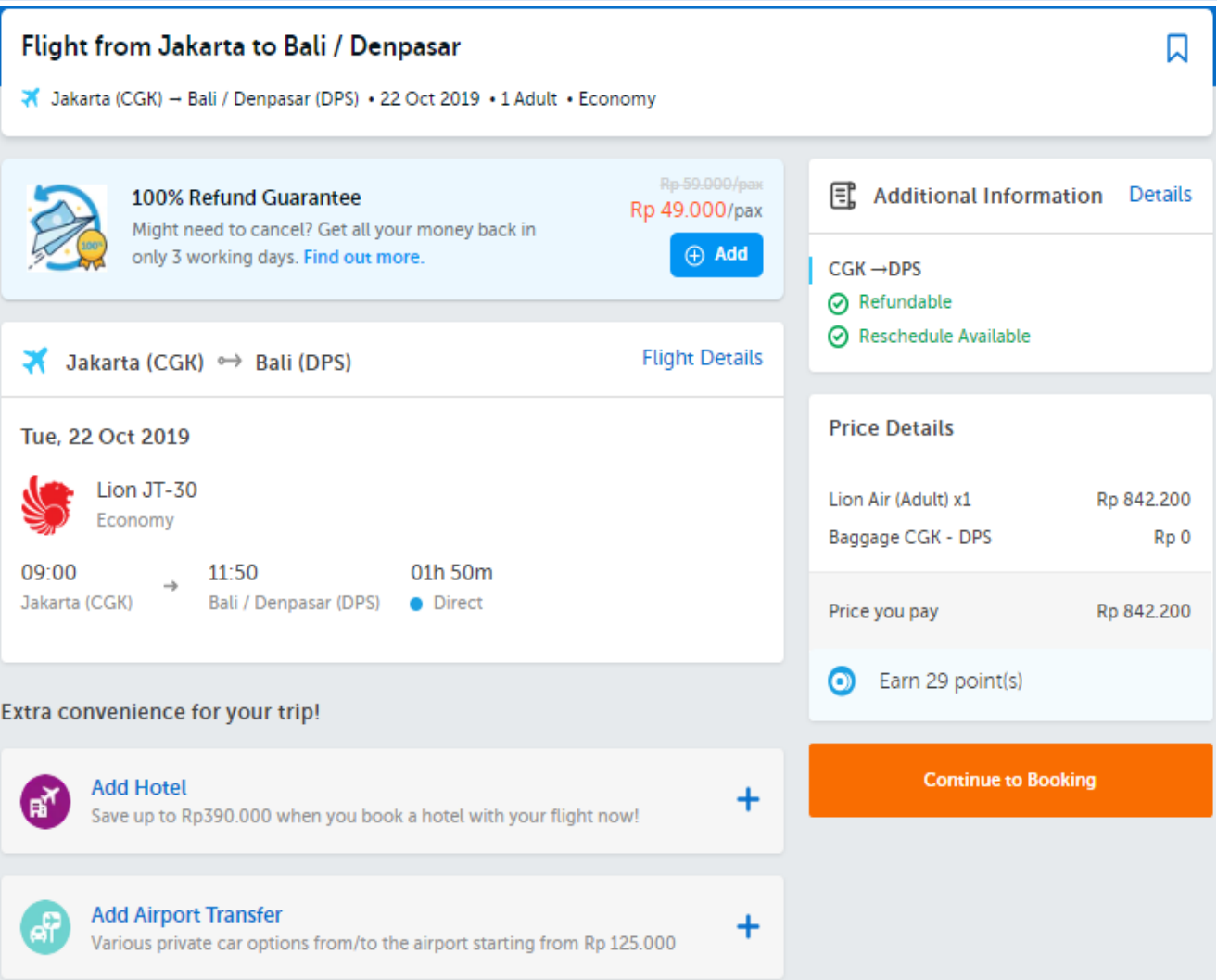

Figure 4. Display after selecting flight ticket prices

Figure 5 shows after determining the selected ticket, the application display detailed information about the flight. Apart from that there are additional options in the form of add hotel features and add airport transfers to choose a hotel or change of planes. 
International Journal of Research and Applied Technology

1(2)(2021) 263-270

Journal homepage: https://ojs.unikom.ac.id/index.php/injuratech

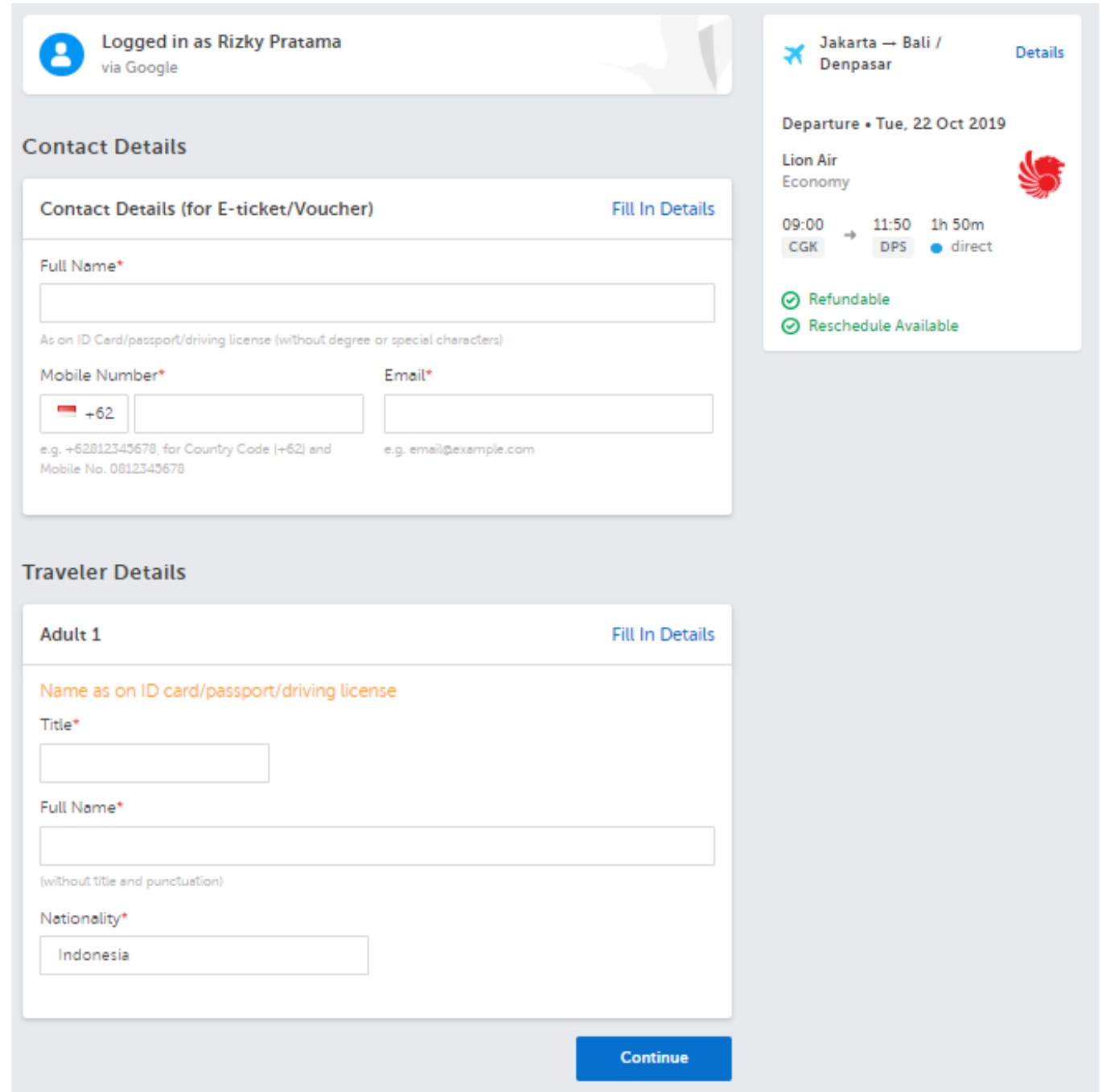

$\overline{\text { Figure 5. Display input of customer contact details and selected flight schedule }}$

Figure 6 shows then the latter will fill in the data about branching such as Contact Details, Traveler Details, and Airline Details. On Airline Details there is a Refundable feature for returns and Reschedule Available for rescheduling flight schedules. 


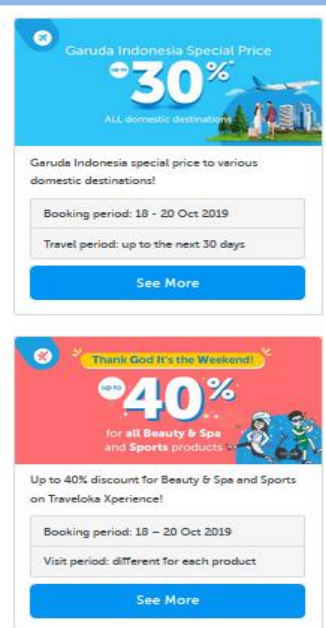

Figure 6. Promos available on online ticket reservations.

The following types of promos are available both for plane tickets, hotel tickets, restaurants, tourist attractions, and others. If the ordering process is done well in advance, it gets a discounted price.

\section{Conclusion}

As a result of the effect of the development of e-commerce, a large influence on people's interest in booking tickets online. Factors underlying the high public interest in online ticket booking are the efficient time of booking and also easy to transact apart from the many facilities available, there are also tempting discounts.

\section{Acknowledgement}

Thank you to the Rector of the Universitas Komputer Indonesia and those who have supported in making this study so it can be completed.

\section{References}

[1] Soegoto, E. S. 2018. Information Technology Based Entrepreneurship Education in University. In International Conference on Business, Economic, Social Science and Humanities (ICOBEST 2018).

[2] Abdullah, M. N., \& Kadhim, E. H. 2016. Airline mobile reservation development. Development, 3(10), pp. 1-3.

[3] Pramiswari, Dewa Ayu Anggi., dan Dharmadiaksa, Ida Bagus. 2017. Pengaruh ECommerce Dan Penggunaan Sistem Informasi Akuntansi Dalam Pengambilan Keputusan Untuk Berwirausaha. E-Jurnal Akuntansi Universitas Udayana, 20(1), pp. 261-289.

[4] Pattiata, G. E., Sparta, J., \& Sin, L. G. 2018. Reshape the Logistics Strategy in E-commerce (Case Study: Shopee and Lazada). In Journal of International Conference Proceedings, 1(1), pp. 5- 10.

[5] Abiola-Oke, E., \& Aina, C. O. 2019. Effect of Online Travel Bookings and Social Media on Tourism Destination Marketing in Nigeria. Advanced Journal of Social Science, 6(1), pp. 10- 16. 
[6] Ajay Kaushik, N., \& Potti Srinivasa, R. 2017. Effect of Website Quality on Customer Satisfaction and Purchase Intention in Online Travel Ticket Booking Websites. Management, 7(5), pp. 168- 173.

[7] Oloyede, M. O., Alaya, S. M., \& Adewole, K. S. 2014. Development of an online bus ticket reservation system for a transportation service in Nigeria. Development, 5(12), pp. 402

[8] Luckyardi, S., Kusnadi, D. J., Santanu, F., \& Subandrio, R. N. (2021). Information Technology in the Social Media Application. International Journal of Education, Information Technology, and Others, 4(1), 6-11.

[9] Ward, J. K., Comer, U., \& Stone, S. 2018. On qualifying qualitative research: emerging perspectives and the "deer" (descriptive, exploratory, evolutionary, repeat) paradigm. Interchange, 49(1), pp. 133-146.

[10] Willis, D. G., Sullivan-Bolyai, S., Knafl, K., \& Cohen, M. Z. 2016. Distinguishing features and similarities between descriptive phenomenological and qualitative description research. Western journal of nursing research, 38(9), pp. 1185-1204. 